\title{
The Initial Stages of the Ontogenesis of Some Medicinal Plants in the Conditions of Bukhara (Uzbekistan)
}

\author{
Shakhina Khalimova Eminzhanovna1, Tashkhanim Rakhimova² \\ ${ }^{1}$ Bukhara State University, Bukhara, Uzbekistan \\ ${ }^{2}$ Institute of Botany of the Academy of Sciences of the Republic of Uzbekistan, Tashkent, Uzbekistan \\ Email: tashkhanim@mail.ru
}

How to cite this paper: Eminzhanovna, S.K. and Rakhimova, T. (2021) The Initial Stages of the Ontogenesis of Some Medicinal Plants in the Conditions of Bukhara (Uzbekistan). American Journal of Plant Sciences, 12, 1624-1632.

https://doi.org/10.4236/ajps.2021.1211113

Received: September 28, 2021

Accepted: November 2, 2021

Published: November 5, 2021

Copyright $\odot 2021$ by author(s) and Scientific Research Publishing Inc. This work is licensed under the Creative Commons Attribution International License (CC BY 4.0).

http://creativecommons.org/licenses/by/4.0/

\begin{abstract}
The article is devoted to the study of the growth and development of medicinal annual Cota altissima (L.) J. Gay and two-year-old Arctium tomentosum Mill., Silybum marianum (L.) Gaertn. belonging to the Asteraceae family in the soil and climatic conditions of the city of Bukhara. The germination of seeds in laboratory and field conditions was determined. Due to unfavorable weather conditions and late spring, the seeds were sown in May. The growth and development of plants was observed one month later. Despite these species, they continue to grow. Cota altissima formed buds and flowers, and Arctium tomentosum and Silybum marianum remained in the virginal age state. All species adapt to the unfavorable conditions of the city of Bukhara.
\end{abstract}

\section{Keywords}

Cota altissima, Arctium tomentosum, Silybum marianum, Seeds, Germination, Climate, Vegetation, Virginal, Generative, Adaptation

\section{Introduction}

The Republic of Uzbekistan is rich in species diversity of wild flora plants (4380 species). Currently, 1200 species have medicinal properties. However, in the republic, more than 100 species of medicinal plants are allowed to be used in scientific medicine, including more than $80 \%$ of which are wild species [1].

To meet the needs of the republic for medicines, an important task is the rational use of wild medicinal plants and the introduction of promising species to ensure the raw material base of pharmaceutical production. Species of the genera Cota J. Gay, Arctium L., Silybum L. are of interest as sources of essential oils, 
glycosides and other substances with valuable pharmacological properties [2]. In this regard, there is a need to study the peculiarities of growth and development in the conditions of culture in different soil and climatic conditions of the republic. Currently, these species are being studied in unfavorable soil and climatic conditions of the city of Bukhara.

According to the natural and climatic conditions, the city of Bukhara belongs to the zone of a sharply continental arid climate typical for the desert regions of Central Asia, which is characterized by a long hot and dry summer and a short but rather cold winter with unstable snow cover up to $5-7 \mathrm{~cm}$ high. The average annual precipitation is $100-200 \mathrm{~mm}$, the average January temperature in the northern part of the region is $2^{\circ} \mathrm{C}$, in the center and in the south is about $0^{\circ} \mathrm{C}$, the average July temperature is $+28^{\circ} \mathrm{C}-30^{\circ} \mathrm{C}$, the absolute minimum air temperature reaches $-27^{\circ} \mathrm{C}$, and the absolute maximum is $+49^{\circ} \mathrm{C}$, the average annual temperature is $+14.7^{\circ} \mathrm{C}-15^{\circ} \mathrm{C}$. The main amount of precipitation falls in the period from October to April-up to $98 \%$ of their annual amount. More than $90 \%$ of the territory of the Bukhara region belongs to the desert (plain) belt [3].

There is little data on the biological features of Cota altissima and A.tomentosum in the literature, and it has not been studied in the republic. The biology, phytocenology and resources of $S$. marianum in the republic were studied in more detail by B. A. Nigmatullaev [4]. Scientific research on the study of ontogenesis in various environmental conditions has not been conducted until recently.

\section{Material and Methods}

Cota altissima is an annual plant, the stem is strong, glabrous or scattered pubescent, leafy, $30-60 \mathrm{~cm}$ tall. The leaves are pubescent, with long scattered hairs. The basket is $25-35 \mathrm{~mm}$ in diameter, on peduncles that thicken with fruits. The lingual flowers are white with a bend of $3-3.5 \mathrm{~mm}$ wide, the disc flowers are yellow. Achenes are slightly compressed, vaguely $3-4$ faceted. It blooms in April-June, bears fruit in late June-July. Weeds in the fields, along the roads, on vacant lots. It is widespread in the Samarkand and Surkhandarya regions, as well as in the Crimea, the Caucasus, Southern Europe, and Iran [5]. It has a high antibacterial effect. The plant is able to slow down the growth of fungi in the body. About 40 species are found in the CIS. Almost all species of this genus are plants with a strong smell and bitter taste, they are not eaten by cattle. Some species contain alkaloids, essential oils, coloring substances and are medicinal plants [6].

Arctium tomentosum is a herbaceous biennial plant of $60-180 \mathrm{~cm}$ in height. The stem is erect, ribbed, reddish, strongly branched in the upper part. The leaves are large, up to $50 \mathrm{~cm}$ long, alternate, petiolate, broad-heart-shaped, whole-edged, less often notched-toothed, green above, grayish-yellow below. Flower baskets are large, spherical $20-35 \mathrm{~mm}$ wide, collected at the ends of the branches in the form of shields with a purple-purple corolla. The root is fleshy, 
rod-shaped, $40-50 \mathrm{~cm}$ long, slightly branched, fusiform. Seeds with a short tuft. Blooms in July-August, bears fruit in July-September, honeydew. It is widespread in the Tashkent, Ferghana and Surkhandarya regions, as well as in Central Asia [5]. It is found almost throughout the entire territory of Russia in Siberia, in the Far East [7]. It often forms large thickets on weedy places near housing, along roads in vegetable gardens, occasionally occurs on the edges of crops, along the banks of rivers and streams. The plant has analgesic, diuretic, hypotensive, hypoglycemic and antistress properties [8].

In the first year, only basal, long-stemmed, large leaves develop. In the second year after the maturation of the seeds, it dies. Dried baskets with mature achenes are easily attached to the fur of animals and people's clothes and are carried to new places. The plant gives a very large aboveground mass and is an excellent silage raw material. It is widely used as a food plant in Siberia, the Caucasus. Soups are cooked from young leaves and petioles or they are prepared with butter. The plant is used for coloring fabrics in green [6]. Toasted root is suitable instead of chicory for admixture to coffee [9].

It contains terpenoids (amerine, lupeol, phytol) and steroids (cholesterol, campesterine, sitosterol) at the root [10]. For medicinal purposes, roots and leaves are used. In folk medicine, the root of the plant is used, which contains starch and traces of an essential oil called burdock. Ointment from the roots is used for hair loss and baldness. From finely chopped roots and young leaves, by cooking with cow oil and water, an ointment is obtained, which gives excellent results in the treatment of burns of all degrees. Seed oil has medicinal use as a laxative and as a remedy for chronic rheumatics.

Silybum marianum is a monotypic genus and species. A biennial prickly plant. The stem is erect, 60 - 1.0 (1.5) $\mathrm{m}$ tall, thin-webby, leafy, branched almost from the base, the branches are single-headed. The leaves are alternate, light green, very short pubescent on both sides; the basal petioles are pinnately separate, prickly, toothed along the edge. The baskets are $3-4 \mathrm{~cm}$ in diameter, almost spherical. The leaves of the wrapper are numerous, ciliated-prickly along the edge. The flowers are tubular, purple, collected in large baskets. Achenes are back ovoid, smooth shiny. It blooms in April-May, bears fruit in May-June. It grows in the Surkhandarya, Kashkadarya and Jizzakh regions. It grows in uncultivated areas, on the edges of roads, in abandoned fields, in oases from the plains to the middle belt of mountains. It is distributed in Central Asia, in the south of the European part, the Caucasus, Central and Southern Europe, Near Asia, North Africa, the Canary Islands [5]. The plant as an ornamental is bred in gardens and vegetable gardens. It grows in vacant lots, in weedy places [2].

In folk medicine, $S$. marianum is used for diseases of the liver, gastric bladder, spleen, chronic constipation, hemorrhoids, articular rheumatics, chronic bronchitis, powdered seeds for the treatment of hepatitis, cirrhosis of the liver, toxic lesions and varicose veins of the lower extremities [2]. In the republic, some bioecological features of $S$. marianum are reflected in the scientific studies of I. 
V. Belolipov, A. Islamov [11]. Scientific research on the study of ontogenesis in various environmental conditions has not been conducted until recently. In this regard, in 2021 we studied the initial stages of ontogenesis in the desert conditions of Bukhara.

Publications on the pharmacological properties of $A$. altissima and $S$. marianum can be seen in international journals [12] [13] [14] [15].

For seed germination in laboratory and field conditions, the methodology of T. A. Rabotnov [16], "Methodological guidelines for seed science" [17], "Handbook on germination of resting seeds" by M. G. Nikolaeva and others were used [18]. The initial stages of plant ontogenesis were studied by the method of T. A. Rabotnov [19] and I. G. Serebryakov [20]. The method of I. V. Borisov [21] and I.N. Beideman [22] was used for the seasonal development of plants.

\section{Results and Discussion}

The latent period. Cota altissima seeds are very small, length $1.8-2.0 \mathrm{~mm}$, width $0.7-1.0 \mathrm{~mm}$. Weight 1000 pcs. seeds $0.3-0.4 \mathrm{~g}$. The optimal germination temperature of seeds is $15^{\circ} \mathrm{C}-17^{\circ} \mathrm{C}$. At this temperature, on the fourth day, the seeds sprouted $15 \%$, on the seventh day- $63 \%$, on the eleventh $-81 \%$ and on the twentieth $-84 \%$. In the field, the seed germination rate was $20 \%-30 \%$ when sown in mid-May.

The Virginian period. Sprouts. The seeds of Cota altissima sown in April did not germinate due to a very cold spring. The seeds were sown again on May 12, 2021 , at a temperature of $27^{\circ} \mathrm{C}-29^{\circ} \mathrm{C}$. Mass shoots are observed after $6-7$ days. During this period, the air temperature was $34^{\circ} \mathrm{C}-35^{\circ} \mathrm{C}$. At the same time, the relative humidity of the air (RHA) is $18 \%$. The length of the sprouted cotyledon leaf in Cota altissima is $2-3 \mathrm{~mm}$, the width is $1-1.5 \mathrm{~mm}$. At the end of the seedling stage, the root reaches $3-4 \mathrm{~cm}$ in length. The stage of seedlings in the life of plants is only 10 - 12 days.

The juvenile stage. At the beginning of June (4.06), the height of Cota altissima seedlings was $1.5-3 \mathrm{~cm}, 3-4$ real leaves are formed. The root deepens 5 - 6 $\mathrm{cm}$, several thin lateral roots are formed. At this time, the air temperature was $40^{\circ} \mathrm{C}-43^{\circ} \mathrm{C}$, the relative humidity was $11 \%-12 \%$. In mid-June (15.06), the number of leaves in juvenile plants increased in the amount of $6-7$, their length with a petiole is $3-4 \mathrm{~cm}$. Cotyledon leaves are still preserved. On June 25, when the air temperature was $28^{\circ} \mathrm{C}-34^{\circ} \mathrm{C}$, RHA $20 \%-21 \%$, intensive plant growth was noted. Plants, without forming lateral shoots, reached $10-12 \mathrm{~cm}$ in height, the number of leaves increased to $11-12$ copies. The root is rod-shaped, deepens $7-8 \mathrm{~cm}$ deep, there are a lot of thin roots of the second order $2-4 \mathrm{~cm}$ long. At the end of this month (25.07) at an air temperature of $44^{\circ} \mathrm{C}-45^{\circ} \mathrm{C}$, RHA $12 \%$, the height reached $14-15 \mathrm{~cm}$, the number of leaves increased to $15-25$ pcs. The plants at this time were in a green virginal age state (Figure 1). At the end of July, Cota altissima had buds and flowers, that is, the individuals were in a generative age state (Figure 2). 


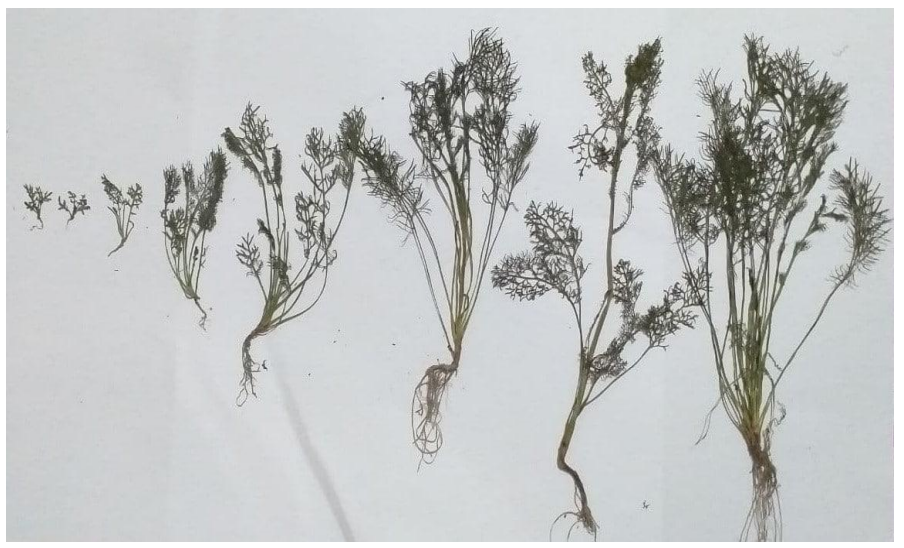

Figure 1. Juvenile and virginal age status Cota altissima.

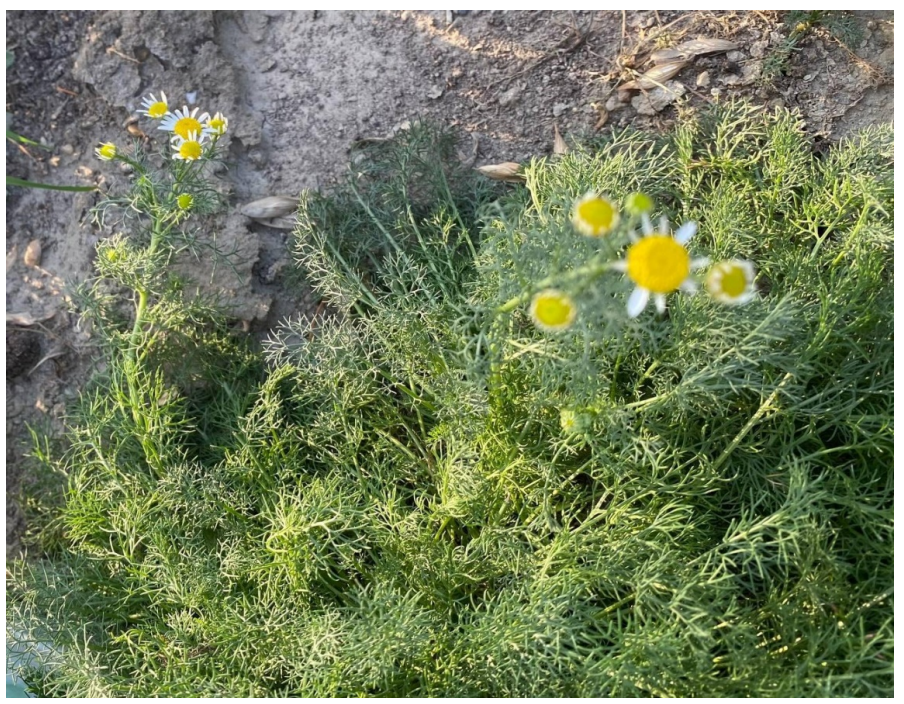

Figure 2. Flowering plant Cota altissima.

The latent period. Seeds of $A$. tomentosum with a short tuft, inversely-conically, with a bluntly cut upper end, granular, transversely wrinkled, grayish - brown, $0.5-0.6 \mathrm{~cm}$ long, $0.2-0.3 \mathrm{~cm}$ wide. Weight 1000 pcs. seeds are $9.8-10.0$ g. The optimal germination temperature of seeds is $15^{\circ} \mathrm{C}-17^{\circ} \mathrm{C}$. Seeds germinate singly 8 days after the start of the experiment, and massively after the 13th, 20th day-77\%. Seed germination lasts 20 - 30 days.

The Virginal period. Sprouts. The seeds sown in mid-May at a temperature of $27^{\circ} \mathrm{C}-29^{\circ} \mathrm{C}$ rose after $6-7$ days. The length of the sprouted cotyledon leaf of A. tomentosum is $0.8-1.0 \mathrm{~cm}$, width $0.3-0.6 \mathrm{~cm}$. At the end of the stage, the root reaches up to $3-4 \mathrm{~cm}$. The stage of germination is $10-12$ days.

The juvenile stage. At the beginning of June, the first and second real leaves were formed, $1.5-1.7 \mathrm{~cm}$ long, $0.5-1.0 \mathrm{~cm}$ wide. The root has deepened to $3-5$ $\mathrm{cm}$. At this time, the air temperature was $40^{\circ} \mathrm{C}-43^{\circ} \mathrm{C}$, RHA $11 \%-12 \%$. In mid-June, 3 - 4 true leaves, $2-2.5 \mathrm{~cm}$ long without petioles, were formed in juvenile plants. Cotyledon leaves are preserved. At the beginning of July, the number of leaves did not increase, but the size of the leaves was $2.5-5 \mathrm{~cm}$ long, 
3 - $4 \mathrm{~cm}$ wide. All leaves are kept green. At the end of this month, the size of the leaves was 5 - $6 \mathrm{~cm}$ long, $4-5 \mathrm{~cm}$ wide. The height of the plants reached $16-18$ $\mathrm{cm}$. The plant was in a green virginal state (Figure 3 ).

The latent period. The seeds of $S$. marianum are oval, faceted, shiny with a tuft. The length of the tuft is $1-1.5 \mathrm{~cm}$ white. The seed size is $5-8 \times 3-4 \mathrm{~mm}$. The color is yellow, from light brown to dark brown. Weight 1000 pcs. seeds are 25 - $27 \mathrm{~g}$. In laboratory conditions, the optimal temperature of seed germination is $20^{\circ} \mathrm{C}-30^{\circ} \mathrm{C}$. At this temperature, the seeds began to germinate on the $3 \mathrm{rd}-4$ th day and amounted to $85 \%-90 \%$. In the field, the seed germination rate was $20 \%$ - $30 \%$ when sown in mid-May.

The Virginal period. Sprouts. Due to the unfavorable cold spring, the seeds were sown in mid-May. Single shoots are observed after 4 - 5 days. During this period, the average air temperature was $32^{\circ} \mathrm{C}$, the relative humidity was $19.5 \%$. The length of the sprouted 5-day cotyledon leaf is $0.8-1.0 \mathrm{~cm}$, the width is 0.2 $0.3 \mathrm{~cm}$, the length of the hypocotyl is $1.0-1.2 \mathrm{~cm}$. At the end of the seedling stage, the root reaches $5-6 \mathrm{~cm}$. At the end of May, the seedlings had a cotyledon leaf size of $1.5-2.0 \times 1.0-1.5 \mathrm{~cm}$, the first real leaves were formed.

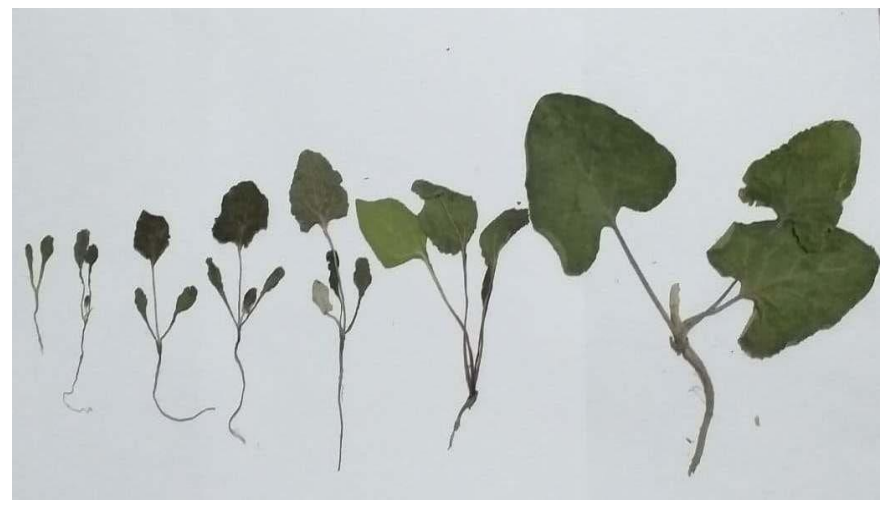

(a)

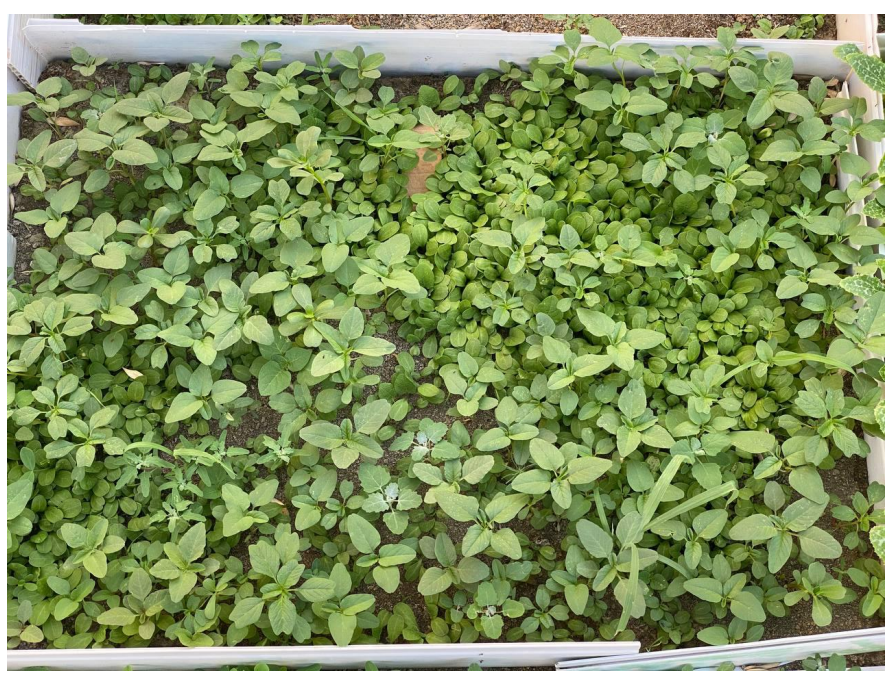

(b)

Figure 3. Juvenile and virginal ((a), (b)) age-related condition, Arctium tomentosum. 
The juvenile stage. In the conditions of Bukhara, the beginning of the juvenile stage (the formation of the first real leaves) was observed in early June. At this time, from one to 4 real leaves were formed, their dimensions are $1.5-2.0 \times$ $0.3-0.5 \mathrm{~cm}$. Some specimens have a leaf length of $3.0-3.5 \mathrm{~cm}$, a width of $1.0-$ $1.2 \mathrm{~cm}$. Cotyledon leaves are still preserved, $3.0-3.5 \mathrm{~cm}$ long, $1.2-1.7 \mathrm{~cm}$ wide. At this time, the average air temperature was $13^{\circ} \mathrm{C}$, the relative humidity was $12.3 \%$. In the middle of this month, at an air temperature of $33^{\circ} \mathrm{C}-34^{\circ} \mathrm{C}$, the relative humidity was $11.5 \%-14.4 \%$, and the number of real leaves increased to 5 - 6 pcs. The plant is still in the juvenile stage. The cotyledon leaves began to dry out. The length of these leaves is $4.0-5.0 \mathrm{~cm}$, their width is $2.0-2.5 \mathrm{~cm}$ (Figure 4). All the leaves are serrated along the edge with yellow spines. At the end of June, at an air temperature of $35^{\circ} \mathrm{C}$ and a relative humidity of $18.8 \%$, the number of leaves did not increase in many juvenile individuals, but the leaf plate expanded, the leaf length was $6.0-7.0 \mathrm{~cm}$, and the width was $3.0-3.5 \mathrm{~cm}$. The main root deepens to $10-12 \mathrm{~cm}$, the lateral ones are $1-2 \mathrm{~cm}$ long with numerous root hairs.

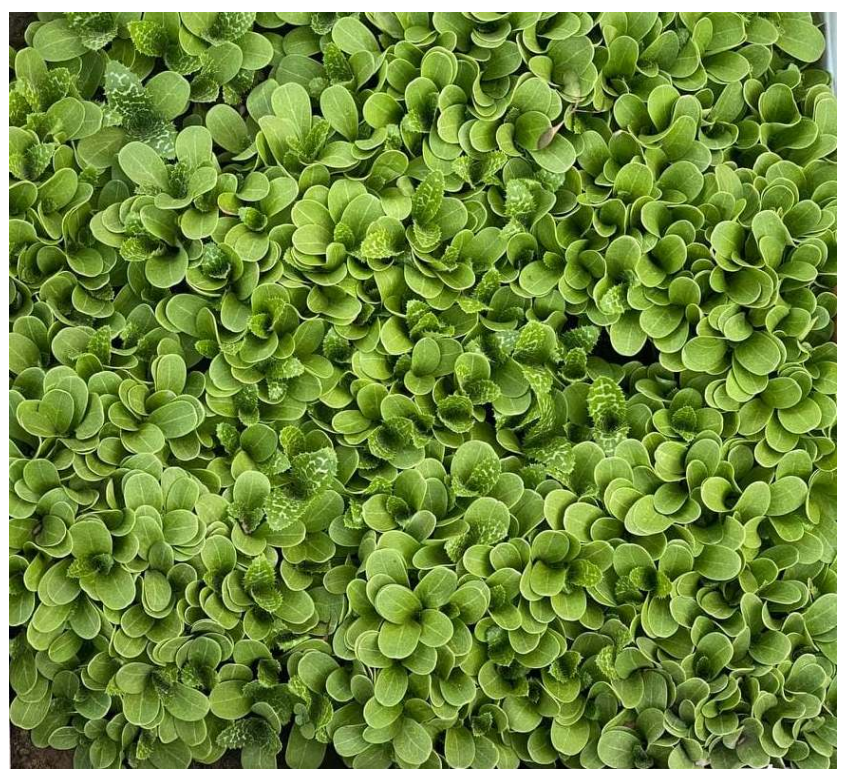

(a)

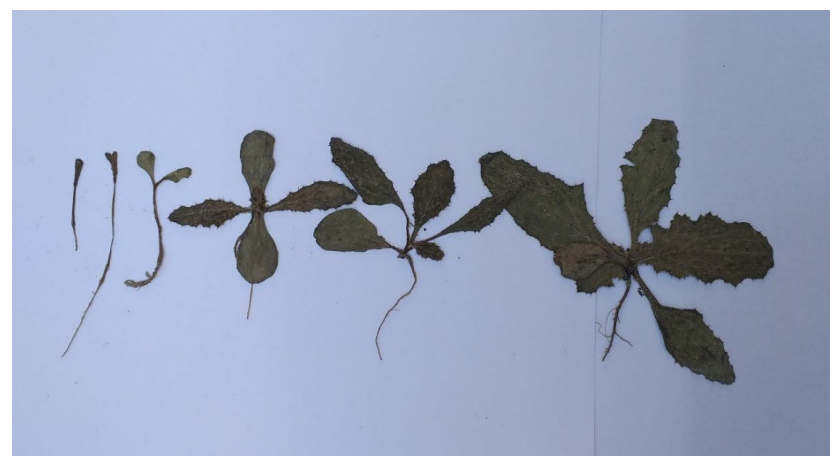

(b)

Figure 4. The juvenile stage of Silybum marianum ((a), (b)). 


\section{Conclusions}

In conclusion, we can say that the studied species is an annual plant Cota altissima in the first year of vegetation reaching the generative period of ontogenesis, and Arctium tomentosum was in a green virginal age state. The biennial plant $S$. marianum in the first year of vegetation remained in the juvenile age state in the form of a rosette of leaves. According to the literature data, generative shoots are formed in the second year of vegetation.

Seeds of medicinal plants, depending on weather conditions, should be sown mainly in the spring (March-April). However, due to the unfavorable weather conditions of 2021, cold, spring frosts in Bukhara, the seeds were sown exactly one month later in mid-May. Despite this, the plant adapts well to harsh climatic conditions. In the first year of the growing season, the growing season of the plant is still ongoing.

Thus, the timing of the phases of budding development, the beginning of flowering, fruit formation, as well as the duration of the flowering and fruiting phases differ depending on soil and climatic conditions. The change in the timing of the passage of these phases in the direction of adaptation to local conditions serves as a reliable criterion for the success of the fitness of the studied species.

\section{Conflicts of Interest}

The authors declare no conflicts of interest regarding the publication of this paper.

\section{References}

[1] Khojimatov, O.K. (2021) Medicinal Plants of Uzbekistan (Properties, Application and Rational Use). Manawiyat, Tashkent, 9-10. (In Russian)

[2] Lavrenov, V.K. and Lavrenova, G.V. (2006) Modern Encyclopedia of Medicinal Plants. Neva, Moscow, 135-136. (In Russian)

[3] Granitov, I.I., Granitov, A.I., Popov, V.A. and Demerza, O.P. (2012) Geographic Atlas of Uzbekistan. Goskomgeodezkadastr, Tashkent, 144 p. (In Russian)

[4] Nigmatullaev, B.A. (2019) Biology, Phytocenology and Natural Resources Silybum marianum (L.) Gaertn. and Onopordum acanthum L. Abstract of Doctor of Philosophy $(\mathrm{PhD})$ in Biological Sciences, National University of Uzbekistan named after M. Ulugbek, Tashkent, 43 p. (In Russian)

[5] Cherneva, O.V. (1962) Flora of Uzbekistan. Vol. 6, Academy of Sciences of the Republic of Uzbekistan, Tashkent, 114, 228-229. (In Russian)

[6] Larin, I.V., Aghababyan, Sh.M., Rabotnov, T.A., Lyubskaya, A.F., Larina, V.K. and Kasimenko, M.A. (1956) Forage Plants of Hayfields and Pastures in the USSR. Vol. 3, Selkhozgiz, Moscow-Leningrad, 596-597. (In Russian)

[7] Shishkin, B.K. (1963) Botanical Atlas. Ed. Corresponding Member B.K. Shishkin. Moscow-Leningrad, 174-175. (In Russian)

[8] Gammerman, A.F. and Yurkevich, I.D. (1967) Medicinal Plants. Science and Technology, Minsk, 231. (In Russian) 
[9] Pavlov, N.V. (1947) Vegetable Raw Materials of Kazakhstan. USSR Academy of Sciences, Moscow-Leningrad, 486-487. (In Russian)

[10] Toyjonov, K., Nigmatullaev, B.A. and Sagdullaev, Sh.Sh. (2016) Etymological Dictionary of Latin Names of Medicinal Plants of Uzbekistan. Navruz, Tashkent, 38 p. (In Russian)

[11] Belolipov, I.V. and Islomov, A. (2001) New Crop for Medicinal Plant Growing in Uzbekistan-Silybum marianum (L.) Gaertn. In: Belolipov, I.V., Ed., Crop Production, Publisher, Tashkent, 10-13. (In Russian)

[12] Samadi N., Manayi A., Vazirian M., Samadi M., Zeinalzadeh Z., Saghari Z. (2011) Chemical Composition and Antimicrobial Activity of the Essential Oil of Antemis altissima L. var. Altissima. Natural Product Research, 26, 1931-1934. https://doi.org/10.1080/14786419.2011.617750

[13] Mustafayeva, S.J., Serkerov, S.V. and Bakhshaliyeva, K.F. (2019) Study of the Composition of Extract and Antimycotic Properties Antemis altissima L. Chemistry of Plant Raw Materials, No. 4, 129-134. https://doi.org/10.14258/jcprm.2019045267

[14] Gasimova, Sh.A., Novruzov, E.N. and Mehdiyeva, N.P. (2017) Study of Chemical Composition of Fatty Oil from Seeds Silybum marianum (L.) Gaertn. Chemistry of Plant Raw Materials, No. 3, 107-111. https://doi.org/10.14258/jcprm.2017031585

[15] Mnatsakanyan, V.A., Ananikyan, G.S., Babakhanyan, M.A., Oganesyan, L.E., Hovsepyan, G.Yu. and Sargisyan, S.A. (2015) Comparative Study of the Content of Fatty Oil and Flavolignans in the Seeds of Silybum marianum (L.) Gaertn. / Soil and Hydroponic Origin. International Journal of Applied and Basic Research, 12, 1445-1447. (In Russian)

[16] Rabotnov, T.A. (1960) Methods for Studying Seed Reproduction of Herbaceous Plants in Communities. In: Lavrenko, E.M. and Korchagina, A.A., Eds., Field Geobotany, Vol. 2, USSR Academy of Sciences, Moscow-Leningrad, 20-39. (In Russian)

[17] Tsitsin, N.V. (1980) Methodical Instructions for Seed Science of Introduced Species. Science, Moscow, 64. (In Russian)

[18] Nikolaeva, M.G., Razumova, M.V. and Gladkova, V.N. (1985) Dormant Seed Germination Guide. Science, Leningrad, 177-178. (In Russian)

[19] Rabotnov, T.A. (1950) Issues of Studying the Composition of Populations for the Purposes of Phytocenology. Problems of Botany, 1, 465-483. (In Russian)

[20] Serebryakov, I.G. (1952) Morphology of Vegetative Organs of Higher Plants. Soviet Science, Moscow, 74-92. (In Russian)

[21] Borisova, I.V. (1972) Seasonal Dynamics of the Plant Community. Field Botany. Vol. 4. Science, Leningrad, 5-94. (In Russian)

[22] Beideman, I.N. (1974) Methodology for Studying the Phenology of Plants and Plant Communities. Science, Novosibirsk, 4-108. (In Russian) 